\title{
The Trajectory of Zimbabwean Marange Diamond Revenue Remittances from 2006 to 2013
}

\author{
Tawanda Manenji \\ Midlands State University, Gweru, Zimbabwe
}

\begin{abstract}
This study attempts to analyze Marange diamond revenue remittances in Zimbabwe from 2006 to 2013. The case of Mbada Diamond Company was used. The information gathered would either validate or nullify the belief that diamond revenues have not been fully attained to date. The Public Choice Theory propounded by Buchanan will help in explaining why such results have been attained in diamond revenue remittance. This paper was compiled after reviewing some government publications, National Budgets, journal articles as well as employing questionnaires and unstructured interviews. The research found that diamond revenue remitting in Zimbabwe particularly Marange fields were still lagging behind the expectations since the start of mining in 2006. Of the expected billions of diamond revenues only about US\$971 million to US\$1.6 billion is believed to have trickled into the Consolidated Revenue Fund (CRF) since 2006. The Marange diamond revenue remittances have proved to be trailing their expectations since the first formal sale was conducted in 2010. This was due to a plethora of challenges which includes weak legislative frameworks, corruption, informal diamond trading, technological incompetence as well as the imposition of economic sanctions to the Zimbabwean economy. The study makes some recommendations as to how the diamond revenues could be fully attained and such remedies among others include internal capacity building, passing of a diamond bill, nationalization of mining companies, introduction of a local mineral beneficiation scheme, multi-collaboration of various ministries in diamond revenue collection and subsidizing the mining of diamond to increase productivity. Zimbabwe's diamond revenues if managed properly, would reduce government external debt, promotes economic development and improves service delivery in the public sector.
\end{abstract}

KEYWORDS: Public Funds, Revenue Reporting, Royalties and Taxes

\section{INTRODUCTION AND LITERATURE REVIEW}

The discovery of Marange diamonds in Chiadzwa district in the Manicaland province in Zimbabwe had revived hopes of the Zimbabwean economy especially when the economy was hard hit by a plethora of economic challenges two decades after attaining its political independence. There is still public outcry in the manner in which diamond mining proceeds have been used to promote national economic growth and development. Since the sale of diamonds has started in 2006, some public policy analysts and concerned individuals have expressed their concern over the manner in which the effectiveness, efficiency, accountability, transparency and credibility have been displayed in the manner in which diamond revenues have been remitted. It was believed that the economy's fiscal space would expand through mining royalties and taxes after close to a decade of fiscal distress. The country had an unmatched and swelling public debt overhang amounting to at least US $\$ 10$ billion as well as a stunning poor service delivery. Massive unemployment rates in the country after the ESAP episode meant reduced tax base and the associated problem of strained budget. Also the closure of some industries had negative implications on the fiscus and as such the discovery of the gem instilled positive hope for refueling the state machinery in the provision of essential services such as transport, health care, education and communication infrastructure. Marange Diamond discovery was believed to bail out the Zimbabwean economy from the scourge of balance of 
payment deficit and scars of the imposed economic sanctions. However, this possibility was only going to be aknowledged if the remittance processes were done in an earnest and transparent manner.

The Zimbabwean economy has been heavily depending on agriculture and mining for the past two to three decades and the mining of gold, platinum and diamond in particular. According to Kwesu in The Herald August 13 (2012:4) mining contributed over 13\% to Gross Domestic Product (GDP) and over 50\% of total exports. Diamond mining has remitted over \$US334 million in 2011 which saw it being ranked $5^{\text {th }}$ world diamond producer ( Jamasmie, Mining.com 2012). Biti (2012:38) in the National Budget noted that 20\% of Zimbabwe's mineral exports are accounted for diamonds and this explains why diamond revenue remittance would be of great deal to scrutiny by economic researchers.

There are at least four mining companies involved in Marange diamonds and among them there is Anjin investments, Mbada holdings, Canadile, (now Marange resources) and Diamond Mining Corporation (DMC). Anjin is partly owned and controlled by the government as well as the Chinese company in a joint venture and it started around 2010, a year after Mbada Holdings' existence. However, some researches by some independent groups shows that Anjin has its shareholding under some retired army generals and ZANU PF's big wigs [www.guardian.co.uk>News>World news>Zimbabwe]. The company was under the western economic sanctions list due to alleged human rights abuse in Marange in the period ranging from around 2010 to date. DMC is believed to be wholly government owned company which came into being in the year 2010.

Mbada Diamonds was founded in August 2009 and is a parity shareholding between the government of the Republic of Zimbabwe through Zimbabwe Mining Development Corporation (ZMDC) through Marange Resources -a wholly owned ZMDC subsidiary-and the New Reclamation Group (South Africa) through Grandwell Holdings, [New Zimbabwe 18 October 2012:8]. Mbada Holdings however got its name listed on sanctions list by United States and the Europeans which has an implication on its object of the business.

Before the discovery of the precious mineral by the national authorities, it was believed that the mineral was subject to massive abuse, smuggling as well as rarely contributing to the government coffers. The discovery of Marange diamonds led to an increased production of the mineral, increased revenue base for the government, increased job opportunities for the local population as well as the establishment of the Kimberly Processing Scheme. However, a lot of questions have been asked concerning the way in which the proceeds are being remitted to the national purse so as per the company's motto-"harnessing diamonds for the Zimbabwean the people".

The public at large has been raising concern on the manner in which this national resource is being used to benefit the intended beneficiaries and the accountability as well as transparency in their disbursements. With the projected growth of the industry expected in the near future, various stakeholders have been worrying about several challenges facing diamond mining such as rejection of the mineral on the international diamond market, technological incapacities, lack of requisite human resources skills, financial incapacities as well as existing corrupt environment in which the industry lies.

\section{CONCEPTUAL FRAMEWORKS}

\section{PUBLIC FUNDS}

Public funds or public revenue is commonly referred to as the Consolidated Revenue Fund (CRF). The CRF can be defined as the national budget or all nations' monies to spend on various appropriations as appropriated by the finance minister. Gundewar (2010:1) defines government revenue as the monies which accrue to the government whether in form of tax revenue, royalty paying, interest, fees, user charges or wealth funds and donations. Mineral revenues is the revenues contributed by the minerals such as diamond, gold, platinum among others and such revenues are paid to the treasury either in form of taxes, royalties, fees, concessions, licensing, signature bonuses, dividends, profit shares and subscriptions. Bannon and Collier (2003:45) give some several ways by which revenues may be remitted and thus defined the term as the practice where individuals, companies and organizations render some funds to the treasury. Revenue remitting of minerals however faces some challenges due to the nature of such resources that is they tend to be public or common property. Bannon and Collier (ibid:17) had to term these resources "conflict triggers", and argued that such revenues might trigger, prolong or finance conflicts in developing economies. Howe 
(1979:241) argues that these resources are amenable to private resource management or ownership because they end up being socially inefficient and people would say, "Get it while the getting is good, why I should save it, if my neighbours will just use it up? Everyone property is no one's property". Bannon and Collier (2003:12) noted that the government should be responsible for the natural resources revenues because there is likely to be a credible scrutiny of the revenues that it receives, how they enter the budget and how they are spend.

\section{REVENUE REPORTING}

Revenue reporting as according to Bannon and Collier (ibid:43) involves the making of the revenue information available publicly through a formal established body as a means to achieve transparency, and curbing corruption, mismanagement and diversion of funds by powerful elites. Such reporting will help the government with important information they need to monitor the ways by which accrued revenues are used but however, according to Bannon and Collier (ibid: 43) such availability of reporting structures will not automatically result in government making better spending choices but rather the elites might end up diverting funds from central government coffers for their personal gains. Revenue reporting also allows the government to calculate taxes due to the government and generally such information includes production, sales, costs and profits levels, Bannon and Collier (ibid:49). Therefore against this backdrop, the state and its influential elites tend not to reveal such information relating to the extent of their revenue resources.

\section{ROYALTIES}

Royalty payment, as one of the several ways of revenue remittance frameworks refer to a certain amount paid to the owner of a resource (usually the state) by the one who's temporarily mining it. Jowitt's dictionary of English law (vol.2, p.1595) defined a royalty as "a payment reserved by the grantor of a patent, lease of a mine or similar right and payable proportionately to the use made of the right by the grantee, but may be payment in kind, that is, of part of the produce of the exercise of the right". Gundewar (2010:11) notes that a royalty is a charge by the owner of a mineral in consideration of the exploitation of mineral resources by the lessee which can be unit, profit or value-based. He further explains that unit-based is based on the tonnage extracted and usually applying to low-value minerals that have a continuous revenue flow. Value-based or ad valorem royalties are paid on the basis of the actual value of the mineral after deducting freight, insurance and storage charges while the profit-based royalty is the most transparent way based on the costs and revenues of a mining company, Gundewar (ibid:11).

\section{TAXES}

Remittances may also be in form of taxes which are compulsory revenue transfers to the central government for public purposes excluding fines, penalties, and social security contributions, Gundewar (ibid:11). Taxes may be in form of value added tax (VAT), fees and customs duties, Bannon and Collier (2003:45). Zimbabwe Revenue Authority (ZIMRA) website (Mechanics of VAT) categorized VAT into two distinct forms which are input and output tax. Input tax is when a registered supplier supplies to another registered operator with goods and services while output tax is when a registered operator in turn supplies those goods and services to traders. The difference between the output tax collected and input tax incurred for making taxable supplies is the amount of VAT payable to ZIMRA. Fines and penalties usually relate to sanction charges fixed for failure to abide by the set rules governing the extraction of a mineral such as failure/delay to pay VAT. Customs duties are revenues to the government from charges on exported or imported goods and user-charges, fees and subscriptions refer to revenues rendered to the government for the permission to operate.

\section{THEORETICAL FRAMEWORKS}

The theory of public choice was used in trying to understand diamond revenue remittance processes in the case of Marange diamonds. Public Choice Theory as proffered by Buchanan (1984:18) attempts to look at governments from the perspective of the bureaucrats and politicians, who compose them, and makes the assumptions that they act based on a budget-maximizing model in a self-interested way to gain influence, purpose and relevance. According to Hill (1999:1) individuals whether in politics or in the market place 
they seek to maximize personal gains at the expense of others whom they ought to represent. Therefore, in relation to this study it is assumed that the theory also assumes that because of limited access to information, bureaucrats tend to make decisions based not on the baseline data or gathered information but on their personal feelings, emotions, values and taste.

Hill (1999:38) wrote that politicians and bureaucrats may be benevolent but have access to limited information such that they end up making decisions generated separately by means of rational self-interest assumptions. In relation to this area of study, the theory assumes that the inadequacy of diamond information has led to some concerned officials taking advantage of that and robs the nation of its revenues. Kemp (1980:49) cements that the theory assumes that the bureaucrats who are appointed by the elites tend to work so as to please those who appoint them. This therefore relates to my study in that those who are entrusted with the diamond revenues will tend not to remit them earnestly while those who should guard against abuse and misappropriations of revenues will also compromise in order to protect their masters' interests.

Against this background, the concept of diamond revenue remittances shall be examined hereunder. It can be concluded from the presumptions made by the public choice theory that the revenue remittance frameworks that are available in the mining industry have been framed only to serve for the purpose of maximization of self interest by the elites. Reporting structures and frameworks might have been designed by government officials and legislators but at an individual perspective/level that is with utility maximization as the main driving force. Bannon and Collier (2003:43) have this to say, "natural resources revenue reporting frameworks are usually weak ...such availability of reporting structures will not on its own result in government making better spending choices but rather the elites may divert funds..." Also, the public choice theory may be used to understand why revenues are usually tempered with by responsible authorities such that in most cases some projects may be undertaken irregardless of unbearable costs attached to them. Bannon and Collier (ibid:53) noted that off-budget funds may be used to finance developmental or prestigious projects of questionable economic or social value where social costs such as pollution, degradation and displacements might be undermined by mining companies at the expense of their private benefits in form of profits and dividends.

The availability of limited information as postulated by the theory also imply that transparency, accountability and credibility tend to be compromised by a self interested individuals who would resort to corruption, financial mismanagement and diversion of funds. Bannon and Collier (ibid:53) have this to say, "the establishment of trust funds or collateral funds which have little public information about the flows through such funds has also meant diversion of natural resources revenues to personal gains".

Therefore the Marange diamonds revenue remitting as a system and its processes is going to be examined in relation to the public choice theory where special attention will be paid to the establishment of the operational legal frameworks, explanations for the current state of diamond sales and revenue remittances as well as the root causes of the challenges faced by the treasury in reporting of diamond revenues.

\section{COUNTRY EXPERIENCES}

\section{BOTSWANA}

Botswana is one of the African countries that are well organized in as far as diamond revenues are concerned. Diamonds represent 33\% of Botswana's Gross Domestic Product (GDP) which is approximately US\$3.3 billion (Basdevant 2008:13) The African Economic Outlook 2006 (www.oecd.org/dev/publications/africanoutlook) notes that Botswana's prudent use of diamond revenues has made it attain middle-income status. African Economic Outlook (AEO) further allude that there is more transparency and accountability in the remittance process where the government has to play the most crucial role in ensuring that there are minimized revenue leakages and pilferage and also by ensuring and enforcing laws (The Mines and Minerals Act) that massively punish those who might be found trying to defraud the nation in any corrupt activity.

About $94 \%$ of total export revenue comes from diamonds in Botswana (Basdevant 2008:13). Bannon and Collier (2003:82) note that Botswana's diamond revenue collection is decentralized with various line 
ministries responsible for collection of such revenues where the Ministry of Minerals, Energy and Water Affairs collecting diamond royalties and taxes on companies. Line ministries make periodic projections of revenues to be collected on monthly basis and submit those to the Accountant General in the Ministry of Finance, Bannon and Collier (ibid: 82). The line ministries will deposit all collected revenues into a single government treasury account in the country's central bank, Bannon and Collier (ibid: 82). Each line ministry will then sends receipts from the central bank of the made deposits to the Accountant General along with some necessary documentation showing how revenues were calculated, Bannon and Collier (ibid:82). This clearly shows some form of accountability being demanded from public officials involved in diamond revenues which will help curb corruption and tax evasions. The Accountant General will then review and records the information and sends it to the Auditor General who, in turn will audits the information, noting the discrepancies between amounts originally estimated, actual amounts to be received and amounts collected before submitting reports to the parliament public accounts committee, which has ultimate oversight of government revenues. The Botswana national government, through its parliament is therefore mandated to ensure that the public officials responsible for diamond revenues have earnestly done so and calling for the Auditor General's office to institute an inquiry where the house is not satisfied or suspect that there was an illegality in revenue reporting. Also, Bannon and Collier (ibid:83) noted that the public accounts committee holds regular hearings, questioning those responsible for estimating and collecting revenues regarding any discrepancies found as well as publishing regular reports on government accounts and the results of hearings.

Zimbabwe's Marange diamond mining could be informed by the Botswana's experience in two major ways. Firstly, Botswana' system is transparent with revenue remittence statement annualy published as required by legislation. Secondly, Zimbabwe could be inspired to rope in the office of the Comptroller and Auditor General (CAG) to audit the submitted financial statements by mining companies as well as reports submitted by revenue officers.

\section{SIERRA LEONE}

In Sierra Leone there has been a long history of diamond mining, which was once the mainstay of the economy however from the late 1970s onwards the diamond trade became increasingly dysfunctional and dominated by corrupt practice and poor policy, Williams et al (2012:5). Diamond net export revenues were believed to increase from \$US50 million in 2002 to \$US180 million in 2006 after an increase in capital investment and the incorporation of both the formal and the informal sectors, Williams et al (ibid:5). As a result of an increase in corruption levels in diamond mining in the country, Williams et al (ibid:5) noted that there is therefore a dire need to enforce new legislation and regulations to combat corruption and introducing professional standards into the industry. Williams et al (ibid:6) further advised that Diamond Act must be gazetted to complement the Mines and Minerals Act of 1996 such that these following aspects would be addressed; (a) Anti-corruption measures and the introduction of standards into the diamond industry; (b) Security matters; (c) Diamond dealing and exporting, and (d) Social aspects of the industry.

Williams et al (ibid: 5) proffered several ways by which anti-corruption measures and introduction of standards may be promoted and among them is;

- Office of a diamond commissioner

- Statement of principles for diamond industry participants

- Reporting standards for diamond industry participants

- Reporting requirements of government offices in respect of diamond industry

- Prohibition on direct and indirect industry participation by civil servants or persons in Government

- Penalties.

\section{OBJECTIVES OF THE PAPER}

1.To determine diamond sales since 2006

2.To establish actual revenue remitta

3.To proffer treasury challenges in as far as diamond revenue remittance is concerned

4. To suggest means through which revenue remittances might be improved in Zimbabwe 


\section{METHODOLOGY}

The research comprises of both qualitative and quantitative data gathering techniques. Primary, secondary and tertiary information were used. Due to the nature of the research topic the researcher dwelt much on secondary as well as tertiary data that is documentary evidence or desk research - reviewing articles, publications, journals, books and websites. Documentary evidence was widely used where newspaper articles, comments, Ministerial reports and budgetary statements were taken into consideration. The method was applied in line with the four research objectives where documentary evidence helped to establish the current state of diamond sales, actual revenue remittances as well as comparing the diamond revenue systems in other nation states so as to depict where challenges emanate from and how best the other societies dealt with those particular situations.

An in-depth interview was conducted and the researcher engaged a principal in the MOF, which is responsible for the management of state funds and revenues. A key informant method was also used in a similar way where an authority in the MMMD was a key respondent. Key informants provide an insight on the nature of the remittence process and also give some recommendations for improvement as aurgued by Carter and Beaulieu (1992). The interview was in form of an unstructured interview where the researcher met the respondent and engaged the key informant in a question and answer session in order to get the relevant information as the discussion unfolded. In some instances the research participant led the researcher to other relevant sources of information as propounded by Neuman (2011).

Questionnaires were designed to add relevance to the study (refer to Appendix A). These questionnaires were completed by authorities in ZMDC, MOF; MMMD ZIMRA. The questionnaires had both closed and open ended questions and the respondents were required to fill in with the appropriate response as well as ticking where applicable.

\section{RESEARCH QUESTIONS}

1. What is the state of diamond sales in the country now?

2. What has been remitted to the government since 2006 ?

3. What are the diamond revenue remittance frameworks?

4. What are the challenges and what should be done to address these challenges in order to improve revenue remittances?

\section{RESEARCH FINDINGS AND DATA ANALYSIS}

\section{RESPONDENTS' PROFILES}

About more than thirty respondents were engaged in this research. Most of the respondents were officials in the MOF, MMMD, ZIMRA, ZELA, ZMDC, MDMC as well as some other accessible local diamond experts, public finance analysts, legislators, economists and the public. These officials as well as individuals in their respective capacities did contribute however, some contributed on conditions of anonymity. Most of them were citing political sensitivities of the subject.

\section{MAJOR FINDINGS}

\section{REGULATORY FRAMEWORKS}

There are several diamond revenue governing statutes which bind different institutions responsible for the handling of diamond revenues such as ZIMRA, MOF, MMMD, MDMC, ZMDC and others. Such legal frameworks include Mines and Minerals Act, Precious Stones Trade Act, Minerals Marketing Corporation of Zimbabwe Act, Zimbabwe Mining Development Corporation Act, Public Finance Management Act, and Diamond policy.

These legal frameworks seek to bring about transparency, responsiveness, accountability as well as inclusiveness in as far as diamond revenues are concerned by providing for revenue reporting systems through corporate taxes, royalty payments, dividend payments, depletion fees and MMCZ commissions. However, there is no clear line of jurisdiction for each and every complementary institution such that at the 
end of day there are gray areas left as well as marring each institution's role as a watchdog to each other. The MOF, ZIMRA, MMMD, ZMDC and MMCZ all are responsible for the collection of diamond revenue dues on behalf of the State governed by either one or two of the Acts. For example, the fact that all these institutions are governed by the Precious Stones Trade Act and diamond policy whilst other legislative frameworks are unique for each makes it difficult to agree on revenue remitting systems and processes. This will create fertile grounds for corruption and abuse of state funds.

In an interview with an official from ZMDC it was highlighted that in as far as these legislative gaps were concerned the State must adopt and implement policies and legislation to develop accountability, openness, personal integrity and financial probity in the government and all public institutions. The Minister of Finance in the National Budget (2012:68) wrote, "It is important that the Zimbabwe Revenue Authority plays its part in the entire value chain of diamonds that is from mining, marketing, to distribution and collection of dues to the Government. This task must be defined by law as demonstrated by the Botswana system. Government of Zimbabwe has to conclude the Diamond Bill as a matter of urgency so as to provide clarity and guidelines on diamond policy.

The table below shows a summary of the governing legislative frameworks in some five key institutions involved in diamond revenues in Zimbabwe.

Table 3.1: Diamond Revenue Remittancing Frameworks

\begin{tabular}{|c|c|}
\hline Name of Institution & Operational legal frameworks \\
\hline Mbada Diamond Mining Corporation (MDMC) & $\begin{array}{l}\text { Precious Stones Trade Act, } \\
\text { Diamond Policy, and } \\
\text { Mines and Minerals Act. }\end{array}$ \\
\hline Ministry of Finance (MOF) & $\begin{array}{l}\text { Mines and Minerals Act, } \\
\text { Precious Stones Trade Act, } \\
\text { Public Finance Management Act, } \\
\text { Diamond Policy } \\
\text { MMCZ Act, and } \\
\text { ZMDC Act. } \\
\end{array}$ \\
\hline $\begin{array}{l}\text { Ministry of Mines and Mining Development } \\
\text { (MMMD) }\end{array}$ & $\begin{array}{l}\text { Public Finance Management Act, } \\
\text { Precious Stones Trade Act, } \\
\text { Mines and Minerals Act, and } \\
\text { Diamond Policy. }\end{array}$ \\
\hline $\begin{array}{llll}\begin{array}{l}\text { Zimbabwe } \\
\text { (ZMDC) }\end{array} & \text { Mining } & \text { Development } & \text { Corporation } \\
& & \end{array}$ & $\begin{array}{l}\text { Mines and Minerals Act, } \\
\text { Precious Stones Trade Act, } \\
\text { MMCZ Act, } \\
\text { ZMDC Act, and } \\
\text { Diamond Policy. }\end{array}$ \\
\hline Zimbabwe Revenue Authority (ZIMRA) & $\begin{array}{l}\text { ZIMRA Act, } \\
\text { Precious Stones Act, } \\
\text { ZMDC Act, and } \\
\text { Diamond Policy. }\end{array}$ \\
\hline
\end{tabular}

Supplied by: The MMMD in an interview (March 2013)

\section{DIAMOND REVENUE INFLOWS FROM 2006 TO 2009}

Nothing trickled into the national purse during this particular period, (Manyeruke and Phiri 2013:21, National Budget 2010:35). This period was described by some economists as the "diamond rush". The activities were still informal and illegal such that revenue collection was impossible. Manyeruke and Phiri (2013: 21) noted that when the scramble peaked in 2008, there were more than 35000 people from more than 15 countries who were involved in illegal diamond mining. According to Kanyenze et al (2012:190) at one time, it was estimated that over 400,000 people were involved in diamond panning in Marange. Operations such as "chikorokoza chapera" and "hakudzokwi" were carried out in 2008 so as to curb revenue loss by trying to bring diamond mining to formality. Due to informal diamond trading during this time there was no room for levying corporate, non-resident and VAT taxes or to collect royalties on mining companies. 
However, this does not necessarily mean nothing was supposed to be remitted to the fiscus as Kanyenze et al (ibid:190) noted that, "the ministry of mines directed the MMCZ to mop up all the diamonds produced in Marange, so the latter established buying points in Marange and Harare to purchase all diamonds. Information on how many were bought, and their value, is not readily available on the market though by July 2008 information indicated that no diamonds had been sold by ZMDC while a number of people had been arrested for being in possession of diamonds from Marange." Sales were actually conducted but the transactions were withheld from public consumption. Also the data provided by Cross (2012:4) suggests that Mbada Diamond's claims has been running at 150 tonnes of ore per hour since the installation of new equipment in 2009. That was equivalent to nearly 1 million tonnes of ore per annum and hence irrational to conclude that nothing was remitted to the government coffers during this period except if it was the case that the companies were on a tax holiday.

An independent analyst who commented on condition of anonymity postulated that this period was purposively extended by greedy, self interested politicians so that they could loot the potential revenues that were mean to contribute to the national fiscus. Cross (2012:2) fortifies this observation by noting that diamonds were being sold at US\$18 per carat in 2009 meaning that sales were actually done but due to some unclear interests, the officials never recorded such sales. Revenues are believed to have been lost to the military groups during this period as Cross (ibid: 4) contents that "The investigations showed that in 2009 , the company processed 25000 tonnes of ore and produced an average of 19.86 carats per tonne and the production sheets were signed by 4 military officers who signed as completed, checked, verified and confirmed by." Also it is believed that though of less significance, the government received revenues through fining apprehended illegal miners. The MOF claimed to have transferred some undisclosed sums of money which was part of the diamond revenues generated in this period to some ministries such as the ministry of education to cater for the economically challenged civil servants which another internal authority at the University of Zimbabwe confirmed that the institution received an undisclosed amount of diamond revenue contributions sometime in 2008/9.

\section{DIAMOND REVENUE INFLOW IN 2010}

The total diamond revenue accumulation for the first and second sales during the year 2010 as recorded by the MOF stood at US\$41 939 188.64. The National Budget (2011:38) notes that, the first and second sales conducted in August and September 2010 generated gross proceeds of US\$56 476194.40 and US\$29 914 788.66, respectively, bringing the total to US\$85 290124.70 and out of this amount, accruals to Government were US\$30 006630.85 and US\$11 932557.79 , respectively. However, out of the amount due to Government of US\$11 932557.79 from the second sale, only US\$8 030151.67 was remitted to Central Government as dividend payment, (National Budget 2011:38). Biti in the National Budget (2011:38) advised for the payments of Royalties, US\$2 881 393.03; Commission, US\$252 121.89; and VAT on commission, US\$37 818.28; made to MMCZ, resource depletion of US\$1 201 197.57, management fees, US\$239 498.95; to be made to the treasury. The third sale which was conducted and later recorded in the 2012 National Budget remitted US\$41 631487.79 totaling US\$174 million combined. According to this data about $87 \%$ of the expected diamond revenues were remitted to the MOF by the end of 2010 .

The MMMD, according to Cross (2012:4) showed concern that about 2 million carats had been exported without the knowledge of the State since the production of diamond in 2010 rose to 23000 carats a day and 8.5 million carats annually. This was also maintained during an interview with an authority in the MMMD. The MOF was therefore suppose to receive about US $\$ 569.5$ million going by the information provided by the MMMD not the provided US\$174 million. Mbada Diamonds' overall price achieved in 2010 was US\$67 per carat not US\$18 given by the Minister of mines, (Cross ibid: 4). He noted that "if we value the Minister's figures for diamonds mined in 2010 at Marange the average price of US $\$ 67$ per carat rather than the figures he gave to the parliament, then the actual value of sales of raw diamonds from Marange in 2010 were US\$563 million and not the stated US\$200 million for the past five years". This shows that about US\$26 million was lost. There is now more concern as to the relationship and coordination between these two ministries when they provide such unmatching figures yet they are suppose to complement each other and come up with uniform figures. Transparency, accountability, responsibility as well as good governance and inclusiveness have been hugely undermined in the diamond processes as evidenced in this observation. 


\section{DIAMOND REVENUE INFLOWS IN 2011}

According to the National Budget (2013:230) the Treasury received a total of US\$233 741247 of diamond revenues out of a targeted US\$400 000000 . This shows that about $58.3 \%$ of diamond revenues were remitted in this year though the figures had shown a general increase in revenues. The diamond revenues remitted during this year as per the figures provided by the Treasury were US\$59 741247 more than that of the previous year. The National Budget (2012:67) notes that in 2011 the MOF received total diamonds dividend receipts of US\$122 256491.67 as indicated on the table below (see Table 3.2). The major reason for the increase in the diamond revenues remitted in 2011 can be attributed to relatively lesser capital investments costs as the companies established and also bringing formalities to illegal miners. During the first years the companies were engaged in the procurements of machinery and equipment as well as infrastructural building to effectively and efficiently extract diamonds in Marange.

The productive capacity for the mining companies was believed to have expanded significantly hence the diamond output was improved from the previous year's output. Also diamond revenue reporting done by the 2010 National Budget where projected and actual remittances were compared and analysed account for the improvements made by the mining companies as well as revenue authorities. This meant levelled grounds for auditing diamond revenues and detection of financial mishandling and abuse.

However, the fact that the expected figures were not met might be as a result of over-estimations made by the MOF, the effects of illegal economic sanctions and diversion of funds by some powerful elites.

Table 3.2 Dividends from MMMD 2011

Dividends from Ministry of Mines 2011

\begin{tabular}{|l|r|}
\hline Date & Amount US\$ \\
\hline 07 February 2011 & $8,386,918.99$ \\
\hline 08 February 2011 & $12,500.000 .00$ \\
\hline 09 February 2011 & $6,200,000.00$ \\
\hline 10 February 2011 & $13,800,000.00$ \\
\hline 16 February 2011 & $689,630.26$ \\
\hline 08 February 2011 & $54,938.54$ \\
\hline 07 March 2011 & $225,000.00$ \\
\hline 12 July 2011 & $12,000,003.88$ \\
\hline 13 July 2011 & $7,000,000.00$ \\
\hline 14 July 2011 & $8,000,000.00$ \\
\hline 31 August 2011 & $23,400,000.00$ \\
\hline 16 September 2011 & $6,000,000.00$ \\
\hline 03 October 2011 & $5,000,000.00$ \\
\hline 04 October 2011 & $10,000,000.00$ \\
\hline 28 October 2011 & $6,000,000.00$ \\
\hline 11 November 2011 & $3,000,000.00$ \\
\hline Total & $\mathbf{1 2 2 , 2 5 6 , 4 9 1 . 6 7}$ \\
\hline
\end{tabular}

Source: National Budget (2012:67)

\section{DIAMOND REVENUE INFLOWS IN 2012}

The Ministry of Mines had promised to pay about US\$600 million to the MOF by the year end December 2012 (Cross 2012:4). Out of the promised US\$600 000 000, the National Budget (2013:230) notes that total 
diamond exports up to October 2012 stood at US\$563 561 495. According to the National Budget (2013:37) the diamonds accounted for 20\% of total mineral exports in 2012. About $94 \%$ of the projected revenues were attained in this year. There was a great improvement in terms of output which might be as a result of employing advanced mining technology and improved diamond information systems demanding more accountability and transparency in dealing with the diamond revenues. The MOF however, had to conclude that "what trickles into the treasury is a drop in an ocean" meaning that only a few revenue is directed into the CRF while the rest is believed to be diverted for personal gains by top elites. The MOF provided the figures of the expected and actual diamond revenues from 2006 to 2013 as follows.

Table 3.3: Actual and Expected Revenues Up To 2013

\begin{tabular}{|l|l|l|l|}
\hline Year & $\begin{array}{l}\text { Expected revenues to be } \\
\text { remitted } \\
\text { US\$millions) }\end{array}$ & $\begin{array}{l}\text { Actual revenues } \\
\text { remitted } \\
\text { (in US\$millions) }\end{array}$ & $\begin{array}{l}\text { Difference } \\
\text { (in US\$millions) }\end{array}$ \\
\hline 2006 & -- & -- & -- \\
\hline 2007 & -- & -- & -- \\
\hline 2008 & -- & -- & -- \\
\hline 2009 & -- & -- & -- \\
\hline 2010 & 200.000000 & 174.000000 & 26.000000 \\
\hline 2011 & 400.000000 & 233.741247 & 166.258753 \\
\hline 2012 & 600.000000 & 563.561495 & 36.438505 \\
\hline 2013 & 400.000000 & -- & -- \\
\hline Totals & 1600.000000 & 971.302742 & 228.697258 \\
\hline
\end{tabular}

Supplied by the: Ministry of Finance During Field Research Interview (March 2013)

\section{DIAMOND REVENUES}

The expected diamond revenues in 2013 were scaled down from US\$600 million the previous year to US $\$ 400$ million. Maybe this was after realizing that the previous expectations were rarely met hence the need to revise the targets downwards. However, considering that the diamond revenues for the year 2012 have surpassed US\$560 million projecting something below US\$600 million is questionable. This might be underestimating diamond revenue performance which might have some negative implications to diamond contributions. The MOF identified projects whose funding will be dependent upon diamond revenues that should be duly remitted to the fiscus. The following table (Table 3.4) presents the Budget areas that are earmarked for funding from diamond revenues. 
Table 3.4: projected 2013 diamond revenues

\section{Projects to be funded from Diamond Proceeds}

\begin{tabular}{|c|c|}
\hline PROJECT & AMOUNT US: \\
\hline \multicolumn{2}{|l|}{ Recurrent Expenditure } \\
\hline Health Delivery Services & $11,000,000$ \\
\hline Basic Education Assistance Module (BEAM) & $8,000,000$ \\
\hline Domestic Arrtesrs - Service providers & $40,000,000$ \\
\hline Referendum & $55,000,000$ \\
\hline Eections & $75,000,000$ \\
\hline LNWTO General Assembly & $6,000,000$ \\
\hline Sub-total & $195,000,000$ \\
\hline \multicolumn{2}{|l|}{ Capital Expenditure } \\
\hline Rosad Construction Equipment & $50,000,000$ \\
\hline Water \& Sanitation Facilities & $40,000,000$ \\
\hline Upgrading of State univensibes Infrastructure & $20,000,000$ \\
\hline Irrigation Retibolimetion and Develepment & $20,000,000$ \\
\hline On-tending to SMEs & $25,000,000$ \\
\hline DIMAF & $30,000,000$ \\
\hline Housing & $20,000,000$ \\
\hline Sub-total & $205,000,000$ \\
\hline
\end{tabular}

Source: National Budget (2013:233)

As highlighted on the table above, diamond revenue remittance systems and processes improved significantly in the year 2013 by clearly providing the projects to be funded and the specific expenditure targets to be met. However, this may create an avenue through which revenue attained after meeting these targets may be diverted from the fiscus.

\section{CHALLENGES FACED IN DIAMOND REVENUE REMITTANCING}

\section{WEAK LEGISLATION}

The various pieces of legislation that govern the diamond revenue remittance systems and processes have proved to be slackening and unsupportive. As a result there is confusion and unclear lines of jurisdiction among key revenue institutions giving birth to task duplication and grey areas. Like the Constitutional Law which is the superior law overriding all other pieces of legislation, the introduction of Diamond Bill will cement these various statutory and provide a general way and direction in collecting and remitting diamond revenues to the CRF. Also people may be tempted to temper around with the diamond revenues where such penalties as specified by the statutory instrument is less punitive. In an interview with an authority in the MMMD it was observed that unlike in Botswana where one would be given a very long term jail sentence in diamond revenue related offence, in Zimbabwe it is usually a small fine or equivalent.

\section{ILLEGAL DEALINGS}

The research has found out that Zimbabwean diamond industry had not yet met the KPCS that would allow its diamonds to be sold with little hustles. This has meant that the local diamonds fetch poor and subsequently low prices on the market where they were mainly being sold on black markets to weak buyers thereby affecting revenue performance. According to the National Budget (2011:37), leakages, arbitrage, compliance with international standards as well as the KPSC scheme affected the diamond revenue 
performance. Manyeruke and Phiri (2013:21) blamed the illegal dealings as a major cause of the loss of diamond revenues especially from 2006 to 2009 . According to them there were more than 35000 people from more than 15 countries who were involved in illegal diamond trade.

\section{ECONOMIC SANCTIONS}

It has been portrayed that the imposed illegal economic sanctions and the Western diamond embargo on Zimbabwean economy have hugely affected diamond revenue performance in the country. The Minister of mines was quoted in the Herald of July 12, 2012 as have said, "Only until the sanctions were removed there was never going to be transparency and accountability in diamond operations." This statement by the Minister may also be used in explaining the implications around diamond revenue reporting. The MMMD claims that sanctions restricts the raising of maximum revenues directly by rejecting local diamonds on the world market and indirectly by exposing them to weaker potential buyers through black markets. Zimbabwean diamonds have just a limited customer base. According to the information released to the researcher by the MMMD the country has resorted to engaging in illegal dealings with the Eastern allies who are however weaker buyers. This could account to the reason why diamond revenues are yet to be fully realized in Marange area as well as at aggregate macro level. Sanctions have also marred transparency and public accountability in as far as diamond revenue is concerned.

\section{CORRUPTION}

The other major issue which resulted in poor revenue generation from Marange diamonds was believed to be corruption and abuse of diamond revenues. Cross (2012:4) highlighted that top officials who are responsible for handling diamond revenues have seen this as an opportunity to rob the nation as there are no effective control mechanisms to monitor and enforce audits. Most public finance officers concerned with the collection of diamond revenues have resorted to using sensitivity and confidentiality as scape goats in covering for their corrupt activities. Implied here was that the public, particularly the media and the civil society were not going to be enlightened about the happenings around diamond sales and revenue hence increased chances for the public officials to apply the public choice theories discussed in chapter two. An independent public finance management analyst who commented on the condition of anonymity said most of the top officials in the institutions concerned with diamonds are nothing but looters of our precious resource who take advantage of the political situation to fatten their pockets.

This fortifies the Partnership Africa Canada report's findings that Marange diamond revenues are diverted by top politicians for furthering their individual personal goals as it wrote "...Mpofu famously rumored to own half of the town of Victoria Falls". The report also published that an estimated two billion United States dollars of diamond revenues has been lost over the past three years whilst an MDC-T member of parliament and economist claimed that about four billion United States dollars worth diamonds were extracted from Marange (http//thinkafricapress.com/ Zimbabwe/diamonds-marange-zanu-pfs-best-friend). The director for the Centre for Natural Resources Governance (CNRG), expressed fears that errant diamond revenues could be used by ZANU-PF to subvert the country's coming elections as argued earlier by Bannon and Collier $(2003 ; 17)$ that natural resources' revenue might trigger, prolong or finance conflicts in developing economies. This however, seems are just questionable allegations by the CNRG director for it is known across the nation that there is a bad blood between him and ZANU-PF after his alleged torture by the later.

The chairperson of ZMDC had to say that the allegations of mishandling of diamond money are totally false and mischievous and all the institutions that are interested in the sales of diamond have the figures.

\section{INSTITUTIONAL INCAPACITY}

The problem of institutional incapacity also hinders maximum benefits from diamond mining as the MMMD highlighted that diamond companies are operating at less than 50\% capacity because of stringent conditions where each is having the capacity to produce 500000 carats per month (that is 2 million carats for four companies) which is US\$140 million per month to make it US\$1 680000000 annually. Moreso, the diamond industry has suffered a huge blow in attracting diamond expects as postulated by Kanyenze et 
al (2012:190). This has the implication that some potential revenues are lost to other developed countries that will process the minerals instead.

The fact that Mbada is a private company makes it not mandated to publish its general annual accounts which might also cause extreme revenue loss. This is explained by the nature of individuals as units of firms that whenever asked something concerning their benefits where such benefits are subject to be charged, they tend not to reveal them earnestly and honestly. Such behaviour of concealing their gains in profits compromise in paying dividends and commissions by diamond mining companies. They just manipulate their profit margins and avoid paying what they should be exactly paying. This shows the applicability of Buchanan's public choice theory that individuals and groups will always seek to maximize self gains at the expense of social benefits.

\section{SOCIAL COSTS}

Huge social costs in form of displacements, pollution as well as destruction of cultural infrastructure and monuments have been experienced in Marange since the discovery of diamonds. The Zimbabwe Environmental Law Association (ZELA) director expressed doubtful concerns about a sound social responsibility by these mining companies as he said the companies have failed to comply with the Environmental Impact Assessments (EIAs) leading to the social destabilization and violent conflicts, destruction of the environment and water pollution in the Odzi river. Little has been done to at least compensate the displaced families as a villager in the area explained that they were never consulted when they were evicted, ZELA 2012 audio report.

However, a statement by the MOM that some revenues might not necessarily go to the government directly but through social welfare and social responsibility might also be used as an explanation for failure to meet the treasury revenue targets by mining companies. He said, "Schools, 'decent homes', roads and other infrastructural developments have been underway since the formal establishments of mining activities in Chiadzwa. In another case, the minister referred to some diamond revenues being given to institutions such as University of Zimbabwe at some point around 2009/2010 which an official at the university confirmed that they received some undisclosed amount of diamond revenues to finance the smooth running of the institution when the economic downturn was at its peak in the country. However, the fact that these transfers were done clandestinely without proper channels being followed makes them amenable to human manipulation as it becomes very difficult to audit the transactions.

\section{HIGH POLITICIZATION OF DIAMOND MINING}

High politicization of the diamond revenues is also a critical issue which has contributed to megre contributions being made by mining companies in Chiadzwa. In an interview held by the researcher at the Ministry of Finance's revenue department the interviewed officials revealed that, "how can we claim our revenues from "her majesty'?" when they were explaining that they (as treasury) tend not to claim diamond revenues from these mining companies for their ownership is under the so called "big wigs" who tend to reluctantly refuse to contribute to the fiscus. This has the implication that corporation taxes, royalties, fees and any other form of revenue that should be remitted to the government will be missed and no action the ministry can take so as to coercively force them to remit their taxes.

\section{CONCLUSION AND RECOMENDATIONS}

\section{CONCLUSIONS}

Other than failure to satisfactorily remit funds to the government there were little or no diamond mining hospitals and schools built, very poor water reticulation facilities, poor public infrastructure, no commendable education funding, unsatisfactory sanitary conditions, huge displacements and culture destruction around Marange diamond mining. 


\section{REMITTED REVENUES}

Diamond revenues remitted to the fiscus are legging behind the expectations from 2006 to date. By the end of 2012 diamond revenue remittances were trailing with a close to US $\$ 230$ million margin. About US\$971 million out of US $\$ 1.6$ billion was received by the MOF after conducting a series of diamond auctioning. Each year the revenues have dwindled significantly. There is also lack of consensus between the revenue figures provided by the MOF and the MMMD with the former claiming lower revenue figures to have been paid into its account whilst the later claimed slightly higher figures.

\section{LEGISLATIVE FRAMEWORKS}

Numerous diamond legislations governing diamond revenues tend to bring an avenue through which revenue authorities might apply the PCT to loot the country's revenues. This is so because there is need for a superior and specific Diamond Act to take precedence over other statutory provisions. The Mines and Mineral Act of 2004 which was being used mostly has proved to be weak, having several loopholes which the politicians tend to capitalize on and fatten their pockets unlike in the Botswana's case that provides for effective punitive measures to fraudsters as well as providing sufficient room for stakeholder participation, and engagement of the more effective and efficient auditing institutions, Bannon and Collier (2003; 82).

\section{CHALLENGES FACED IN DIAMOND REVENUE REMITTING}

Diamond revenue remittance in Zimbabwe has faced a multiplicity of challenges across the time of study. Among these challenges include poor revenue reporting structures in the diamond industry, institutional incapacity in the ministry of finance resulting in revenue leakages, corrupt tendencies by revenue authorities, the application of the public choice theory by revenue authorities and mining companies' shareholders, poor technology which has resulted in over-estimations of diamond revenue generations, lack of more competent diamond experts in the country, lack of adequate diamond information available to the public for proper audits, weak information management systems that may have undermined the role of stakeholders in ensuring accountability and transparency within responsible revenue authorities as well as illegal sanctions and embargoes imposed on the country by the Western allies. Insurgence of black markets as a result of the effects of illegal sanctions has led to loss of some potential revenues as some revenues will fall outside proper channels and institutions that can be taxed.

\section{RECOMMENDATIONS}

\section{CAPACITY BUILDING}

The study recommends a multi-sectorial collaboration of various ministries in the collection and submission of diamond revenues coupled with a good package of effective information systems that is implementation of PFMSs. This will empower the public as a watchdog in management of public funds. Auditing becomes easier, transparency and accountability will also be enhanced as such information becomes available and accessible to key institutions such as ZIMRA, CAG, MOF among others. There is also need to engage ZIMRA in the entire value chain of diamonds from mining, marketing, sale and collection of dues to the government so as to reduce revenue leakages. This will help achieve better remittances for this has worked quite significantly in Botswana as discussed earlier on.

Measures must also be taken to expose, combat and eradicate corruption and abuse of power by those holding political and other public offices to do with diamond revenues through enactment of the Diamond Act. The State must encourage the publication of information about diamond processes, marketing and sales, in so far as publication of that information is consistent with good government and public security. The State must also ensure that all Commissions and other bodies established by or under the Constitution for diamond revenue generation, monitoring, reporting and auditing are provided with adequate resources and facilities to enable them to carry out their functions effectively and efficiently as envisaged by the Constitution or enabling legislation. 


\section{NATIONALIZATION}

The study has established that Marange diamonds were mined under multiple ownership scheme as five companies were licenced to partake mining activities in the area. It can be deduced that the government has failed to control these mining companies hence the need to nationalize them so as to ensure the resource will be made to benefit the public at large rather than leaving the self interested individuals internalize the benefits that are meant to be externalized.

\section{REFERENCES}

[1] Bannon I. and Collier P. (2003). Natural Resources and Violent Conflict: Options and Actions. World Bank; Washington DC

[2] Basdevant O. (2008). Are diamonds forever? Using the permanent income hypothesis to analyze Botswana's reliance on diamond revenue. [Online] Accessed at://http $\mid$ www.oecd.org/countries/Botswana/49712253.pdf. [accessed on 20 February 2013]

[3] Buchanan J. M. (1984). Politics without romance: Sketch of positive Public choice theory and its Normative implications. University of Michigan Press, Michigan.

[4] Carter, K..A. and Beaulieu, L.J. (1992). Conducting A Community Needs Assessment: Primary Data Collection Techniques. University of Florida, Gainesville.

[5] Chiketo B. (2013). Zimbabwe Marange Diamonds: ZANU PF's Best Friend? [Online:www.thinkafricapress.com/Zimbabwe/diamonds-marange-zanu-pfs-best-friend). [Accessed 17 February 2013]

[6] Cross E. G. (2012). Mpofu diamond revenue from Marange untrue. [Online:www.thezimbabwean.co.uk/comment/blog [accessed on 27 February 2013]

[7] Cross E. G. (2012). Parliamentary Report on Marange Diamonds. Government of Zimbabwe.

[8] Government of Zimbabwe: National Budget Statement 2010.

[9] Government of Zimbabwe: National Budget Statement 2011.

[10] Government of Zimbabwe: National Budget Statement 2012.

[11] Government of Zimbabwe: National Budget Statement 2013.

[12] Gundewar C. S. (2010). Mineral Royalties. Indian Bureau of Mines, Nagpur.

[13] Hill P. J. 1999. Public choice. A review. Gordon College, Boston.

[14] Howe C. W. (1979). Natural Resource Economics. Issues, Analysis And Policy. John Wiley and Sons, New York.

[15] Jamasmie C. (2012). Diamond revenue remittances in Zimbabwe [online: www.mining.com/nobody-knowswhere-the-diamond-revenue-is-going/. [Accessed: 20 September 2012]

[16] Jowitt Dictionary of English Law. Vol 2 p. 1595

[17] Kanyenze G. et al (2011). Beyond the enclave. Towards a pro-poor and inclusive development strategy for Zimbabwe. Weaver Press; Harare.

[18] Kemp M. C. and Long N. V. (1980). Exhaustible resources, optimality, and trade. Contributions to economic analysis. Amsterdam; North Holland

[19] Kwesu I. (2010). The Chiadzwa diamonds in fresh controversy. The Herald, 31 January, 1-2

[20] Manyeruke C. and Phiri C.G. 2013. Complexities of transformation in Zimbabwe. OSSREA; Harare

[21] Mines and Minerals Act: Government of Botswana

[22] Mines and Minerals Act (1996) Government of Sierra Leon

[23] Ministerial Report 2012, Ministry of Mines and Mining Development, Government of Zimbabwe

[24] Ministry of Mines and Mining Development Act 2004. Government of Zimbabwe.

[25] New Zimbabwe 18 October 2012

[26] Neuman, L. (2011).Social Research Methods: Qualitative and Quantitative Approaches. Pearson, Boston.

[27] The African Economic Outlook 2005-2006 [Online:www.oecd.org/dev/publications /africanoutlook]

[28] Williams J. et al (2012). Sierra Leone: Diamond Policy Study. Pdf. [Online: www.s4rsa.wikispaces.com/file/...Sierra+Leone+Diamond+Policy+Study+2002.pdf]

[29] ZELA Audio Report: The impact of mining on local communities. A case study of Marange, Zimbabwe. Dreamers Productions, Harare.

[30] Zimbabwe Revenue Authority website 